\title{
Beta Endorphin-Healing Potential
}

\author{
Shrihari TG* \\ Department of Oral medicine and Oral oncology, India
}

ISSN: 2578-0093

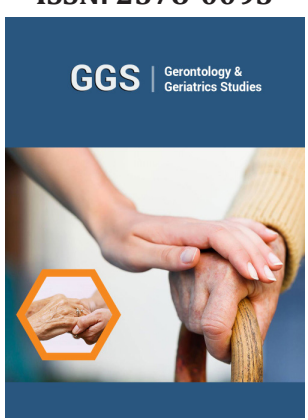

*Corresponding author: Shrihari TG, Department of Oral Medicine and Oral oncology, India

Submission: 涀July 29, 2020

Published: 海October 09, 2020

Volume 6 - Issue 2

How to cite this article: Shrihari TG. Beta Endorphin-Healing Potential. Gerontol \& Geriatric stud. 6(2). GGS. 000635. 2020 DOI: $10.31031 /$ GGS.2020.06.000635

Copyright@ Shrihari TG, This article is distributed under the terms of the Creative Commons Attribution 4.0 International License, which permits unrestricted use and redistribution provided that the original author and source are credited.

\section{Abstract}

Betaendorphin is an abundant endorphin, more potent than morphine. It has got analgesic, antiinflammatory, immunestimulatory, and stress buster activity. Betaendorphin can be used in preventive, therapeutic, health promotive and palliative management of various diseases without adverse effects and inexpensive.

Keywords: NF-KB; STAT-3; HPA-AXIS

Beta-Endorphin and Its Mechanisms of Actions

Beta-endorphin is an abundant endorphin, more potent than morphine, synthesized and stored in the anterior pituitary gland; it is a precursor of POMC (Proopiomelanocortin). Endorphins are produced during yoga, pranayama, intense physical exercise creates a psychological relaxed state known as 'Runner's high', Love, tender, care, acupuncture, music therapy, dancing, singing, mindful meditation, sex, sympathy, empathy in caring the patient [1-4]. Beta-endorphin receptors are situated on the immune cells and nervous system. Betaendorphin binds with $\mu$ receptors situated on the peripheral nerves results in inhibition of substance $\mathrm{P}$, a neurotransmitter of pain and inflammation. Beta-endorphin binds with $\mu$ receptors situated on the central nervous system results in inhibition of GABA inhibitory neurotransmitter, produce dopamine neurotransmitter involved in analgesic activity, tranquility of mind (Stress buster activity), cognitive development, self-reward, euphoria, and addiction.

In an inflammatory state, binding of beta-endorphin to the $\mu$ receptors situated on the peripheral nerves results in inhibition of substance $p$, a neurotransmitter of pain and inflammation, produce anti-inflammatory cytokines such as IL-10, IFN- $\gamma$ to reduce inflammation. Beta-endorphin receptors situated on the most innate and adaptive immune cells. Binding of beta-endorphin to the $\mu$ receptors situated on the innate and adaptive immune cells such as neutrophils, macrophages, natural killer cells, dendritic cells, mast cells, T cells, and B cells results in inhibition of IL-1 $\beta, I L-6, T N F-\alpha$ pro-inflammatory cytokines, which inhibit the activation of NF-KB a key transcription factor involved in chronic inflammation, tissue damage and activation of innate and adaptive immune cells (immune stimulatory activity) results in release of IFN- $\gamma$, opsonin, granzyme-B, and antibodies results in antiinflammatory activity, anti-viral activity, anti-bacterial activity, anti-tumor activity [1-8]. All these mechanisms of actions of beta-endorphin helpful for future management of diseases such as heart diseases, Alzheimer's disease, cancer, diabetes mellitus, infectious diseases, and aging without adverse effects and economical. Thorough understanding of beta-endorphin, mechanisms of actions, dose dependent duration of action needed for application in management of diseases.

\section{References}

1. Shrihari TG (2017) Endorphins on cancer: A novel therapeutic approach. J Carcinog Mutagen 8(4): 298.

2. Shrihari TG (2018) Endorphins- A novel hidden magic holistic healer. Journal of Clinical and Cellular Immunology 9(2): 547-552. 
3. Shrihari TG (2018) Endorphins-A forgotten hidden magic holistic healer: Minireview. Advances in Complementary \& Alternative Medicine 2(5): 170-172.

4. Shrihari TG (2018) Beta-endorphins-a novel natural holistic healer Journal of Microbial and Biochemical Technology 10(2): 10-14.

5. IwaszkiewicZ KS, Schneider JJ, Hua S (2013) Targeting peripheral opioid receptors to promote analgesic and anti-inflammatory actions. Front Pharmacol 24(4): 132-137.
6. Hua S (2016) Neuroimmune interaction in the regulation of peripheral opioid mediated analgesia in inflammation. Front Immunol 2(7): 293298.

7. Shrihari TG (2017) Quantum healing approach to new generation of holistic healing. Transl Med 7(3): 198.

8. Chang QZ, Dipak KS, Wendie SC, Nicholas TB, Paul ET (2013) Role of Beta-endorphin in control of stress and cancer progression in fetal alcohol exposed rats. Thesis.

For possible submissions Click below: 